- Alexander Michael Tjahjadi dan Derajad S Widhyharto Universitas Gadjah Mada

\title{
Youth Within Transition: Recent Developments in Education and Employment in Yogyakarta
}

\begin{abstract}
A B S T R A C T
Yogyakarta as a parameter for the development of national education offers potential young and educated human resources. It is hoped that this potential will trigger youth's productivity to contribute in the demographic bonus and national development. From the perspective of economic growth, Yogyakarta tends to have an increasing trend when compared to that of national economy which tends to decline. However, the increasing trend can become a problem when the educated youth are unproductive and fails to transition from education field to working field. The data of Yogyakarta's GDRP from 2003 to 2013 shows a dependency on the trading, tourism and services sectors. Optimism towards those three sectors do show a percentage increase, but it is not in sync with the education potential and employment for the youth. There is a transition from young labour who are self- or family-employed into low-rank employees and paid labor. There are at least two effects of this phenomenon. First, the data shows that the number of unemployed youth become stagnant with high school as the highest completed education. This indicates a hindrance for transition among youth from secondary education to higher education. Second, this obstacle prevents youth from moving into a higher income bracket and traps them in below-average wages. In reality, economic growth is still reliant on the services and consumption sectors, thus a transitory approach is needed that can involve the youth not as an object but as a main feature of Special Region of Yogyakarta is needed.
\end{abstract}

Keyword: Youth Transition, Demographic Dividend Education, Employment, and Yogyakarta

\section{Introduction}

Indonesia, represented by the Ministry of Manpower has signed G 20 declaration in Beijing in July 2016, the declaration contains an agreement regarding a policy recommendation towards youth unemployment, by increasing skills according to the labour market, increasing the quality of apprenticeship and sustainable, rational, and coherence wage policy principles. The G 20 members have agreed to achieve the goals by 2025 .
Indonesia's involvement in signing the declaration is not a heedless move, until 2045 Indonesia will be in the midst of demographic dividend where the amount of young productive age is at its highest, this is what caused the government to come and sign the declaration. Furthermore, data from Indonesia's Central Bureau of Statistics shows that in $20149.5 \%$ (688.600) of the unemployed have either gone to a vocational school or even university. From the $9.5 \%$ the highest unemployed, 495.143 persons, came from the former university student with a bachelor degree. It turns out that it is not 
those who have lower than high school education that are unemployed the most, but rather those with vocational and college degree. On the contrary, there is a surplus of the worker for those with common middle and high school degree. This problem has given rise to many job vacancies filled with the incompetent worker. Decreasing the skill mismatch, is an urgent matter to strengthen the competitiveness and productivity of Indonesia's economy.

Such condition affects Indonesian youth wage and productivity, the minimum wage growth rate according to International Labour Organization (ILO) report of 2014-2015 has risen way above the average, this trend reflects a huge dependency in establishing a minimum wage and emphasize the need for collective bargaining to promote the average wage growth. In addition, to understand the trend of minimum wage and average wage, we need to examine the wage distribution by observing the median wage. There is a disparity between Indonesia's average wage and median wage, where the average wage is around Rp1952.589 on August 2014 meanwhile the median wage is around Rp1.425.000 on the same period. It shows that distribution of permanent worker according to the wage is very uneven, there are still many workers that receive unfair wage.

Further analysis of the ILO 20142015 report shows that one in three permanent workers in Indonesia is the youth $(33.6 \%)$ receiving a low wage (two-thirds of the median wage). Therefore, some specific policies are needed to overcome the high number of low-wage cases in Indonesia. Overcoming low wage cases is very important to strengthen productivity and competitiveness of Indonesia's workforce, low wage causes a decline in workers' skill and acts as a signal to the employer that the worker has a low productivity. Such condition affects the economic logic of domestic demand. Household expense rate for consumption that is being supported by investment from poverty reduction programme and the increase of minimum wage promotes an increase in household income and encourage enhancement of average demand. Household expenses are $56.1 \%$ of 2014 GDP. Keeping in mind that citizens of Indonesia are predicted to increase to 271 million in 2020 and 306 million in 2035, such strong personal consumption is predicted to come from the same groups of youth demographic dividend, they are the one who will propel Indonesia's economic growth.

The development of Yogyakarta City and the enhancement of higher education industry show a relation between the youth, education, and workforce in Yogyakarta as a parameter of youth education and workforce based demographic dividend development. Yet, the reality is not that different from other cities. The low-income trap is still a problem for Yogyakarta, Special Region of Yogyakarta held the title as the most unequal province in Indonesia. Indonesia's Central Bureau of Statistics states that Yogyakarta's gini ratio as September 2016 is 0,425 , higher than it was in March 2016 and September 2015, which was 0,42. From all 10 of the most unequal province in September 2016, five of them are located on the island of Java, including Special Capital District of Jakarta. From that list, six provinces have above 0,4 gini ratio. That is to say that the six of them categorised as having moderate inequality. Gini ratio is an indicator to illustrate inequality with a range of $0-1$. The number 0 means perfect equality and the number 1 means perfect inequality. If the number is $<0,4$, it is considered as low inequality, in the range of $0,4-0,5$ considered as moderate inequality, and >0,5 considered as high inequality.

On praxis level, Yogyakarta is having a youth workforce surplus with high school degree, which is more than half of the percentage of youth working in the city 
$(56.7 \%)$ and the village $(50.17 \%)$. Such great number is what makes Yogyakarta's condition is pretty much the same as what is happening on the national scale, even if Yogyakarta held a high potential of youth studying in higher institution. Even in the village area, the number of youth working with a middle school degree is still very high, $35,01 \%$, the same goes with the number of youth working in the city, only $22.49 \%$ of them have a higher education degree. The data shows that, first, the number of youth unemployed or seeking for work is stagnant, with high school as the highest educational attained. Indicating a hindrance for the youth to attain higher education. Second, this is what has been making the youth unable to move to a higher income bracket and stuck at the lower than national average income. See diagram 1.1 below.

Diagram 1.1. Percentage of Youth working and Latest Education Special Region of Yogyakarta 2015

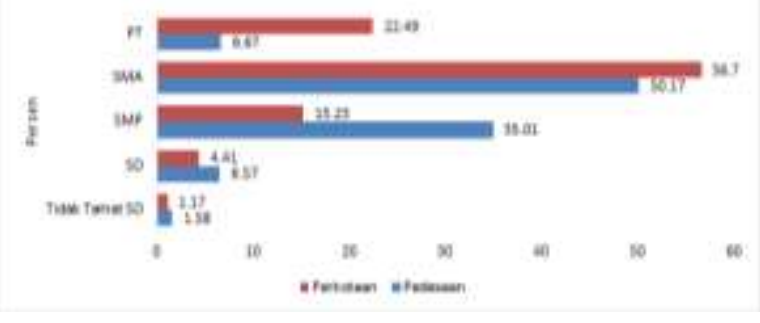

Source: Badan Pusat Statistik (2016), processed

The statement above is interesting to review considering the occurrence is unobserveable in a short period of time but the impact can be felt in the long run. As for the impact, there have been an emerging of unemployed person with high educational degree which is felt the most by the youth in productive age, the abundant of workforce with high school degree causes lower minimum wage, forcing workforce with a higher educational degree to follow the flow of high school graduates. As a result, a brain drain occurs, potential and productive workforce left their place of origin to seek better opportunities and prosperity. This condition is counterproductive with the spirit of regional development and the speciality concept of Yogyakarta. Yogyakarta's limited natural resources potency resulted in trade and services being the pedestal for its people life development. It is marked by the people's enthusiasm to learn and go to school, such that Yogyakarta obtain the predicate of students and education city. This condition affects the development of jobs availability and human resources that tend to support such sectors. Contradiction appears when there is no job to absorb the abundant workforce produced by various schools and other educational institution. The gap between jobs and the workforce is widening and the reality in the field shows that the jobs that are intended for middle until high school graduate is filled by university graduate. This condition also differentiate Yogyakarta with other cities.

As an instrumental element of society, youth has a very strategic role in the development of Indonesia in general and Yogyakarta in particular. Furthermore, this research will answer two main problems. First, whether the youth become a subject or an object in the development practice especially in Yogyakarta region, second, what is the effect of education in term of youth employment in Yogyakarta region.

\section{Research Method}

Methodologically, traversing such problem contain a strategic value and beneficial for stakeholders in the region to manage demographic dividend. Responding the problem will be relevant if this review emphasise literature reviews that refer to secondary data generated by governmental institution that's being supported by Act No. 14 year 2008 regarding public information disclosure act. Therefore, researcher deliberately limiting the data from the year 2003-2013, as for the data used obtained from Indonesia's Central Bureau of Statistics 
namely Statistik Pemuda Indonesia, in order to convince the policy maker. Therefore, literature study and secondary data analysis are the best option to trace back the dynamics of educational and youth employment data in Special Region of Yogyakarta.

This research uses secondary data analysis to be tested quantitatively. The reason is to see the complete and consistent condition according to existing situation (Kuncoro, 2013). This research uses three sources taken from Survei Sosial Ekonomi Nasional (Susenas) that have been processed in Statistik Pemuda Indonesia, Survei Tenaga Kerja Nasional (Sakernas), that have been processed in Indikator Tenaga Kerja, and data from Indonesia Family Life Survey (IFLS). Secondary data analysis is used for cost effectivity and time-saving (Kuncoro, 2013).

The use of IFLS's data in this research is to observe the status of workers education and wages received. Moreover, IFLS also has a growing number of samples since its release. IFLS covers more or less 70 thousand individuals that are spread mainly across 13 provinces. The number of individuals are equivalent with $83 \%$ of Indonesia's population. The advantage that BPS does not have is that IFLS has a very long range and served as panel data, enabling to analyse changes in the same individual.

Furthermore, the use of literature review as secondary data was executed by processing the data using descriptive study. Descriptive study is a form of analysis to deduce raw data so that it is able to be interpreted especially using central tendency measurement. Researcher also uses graphical method to see the relation between one variable with another variable.

We believe that there are more limitation in conducting this secondary data literature review. Some of that are the lack of periodical youth survey done by BPS, until now there is no youth survey with a long range of time. This then became the reason for researcher to use five years interval starting from 2003. Therefore this research has different value-added to other researches.

This research has the risk and opportunity of development, using a multidisciplinary approach, combining the concept of sociology and economics at once. It is expected to give variation in literature study. On the other hand, educational transition shift towards work may use study of a more complex quantitative research method. However, this research only includes and refers to quantitative data, from secondary literature analysis that does not represent all phenomena occurring in the society.

\section{Approach and Previous Study}

Youth transition is a result of social construction and contestation of power. Youth is entering transition dimension from education field to working field (Robinson, 2016). Yogyakarta's youth education transition to the working field is also a common youth phenomenon in other region in Indonesia. It matches with the research done by Kathryn Robinson in a book entitled Youth Identities and Social Transformation in Modern Indonesia. The book gives, at least, an illustration of various regions in Indonesia possessing the phenomenon of education to working field transition. Ambivalent Adolescents in Indonesia (AAI) survey research that involve purposive sample of high school students from nine location accross Indonesia. AAI survey compares the viewpoint of children ages 16 to 18 from city and countryside and from Islamic school and secular school. This survey also researched the trend and similarities of the life of Indonesia's youth in the fist decade of $21^{\text {st }}$ century especially in the field of life expectancy, social life, pop culture, recreation, sexuality, and jobs. The term "transition" here refers to the journey from education field to adulthood, jobs or career, marriage, and parenthood. It can also 
be seen in White's writing in the same book (Robinson, 2016). Still discussing about youth transition. Sutopo in his writing states that one of the face of transition that will be discussed in his writing is the transition from education field to the working field. Specifically youth from the educated class (vocational or unversity graduates). This preference is based on the argument of Naafs and White (2012) that explains that the educational level of Indonesia's millenial youth is increasing compared to that of the previous generation. However, this increase is not followed by the government's ability to create jobs. This problem has been occuring for long and the solution is yet to be found be it the New Order era or the Post-Reform era. Responding to that, the emphasis of Sutopo's writing (2013) of youth transition from the education field to the working field shows that the youth is actively implementing the long term strategy. Accumulating and converting capital, as well doing zigzag journeys during the transition period.

The dimension refers to two social construction aspects, which are formal and non-formal (Robinson, 2016). The formal aspect includes youth that are undergoing education. They are hoped to finish the required education to fill formal jobs that emerge from the country's necessity. Such as civil servants and working in the industrial sector corresponding to their educational background. Therefore we often hear those who go to school mention doctor, soldier, engineer, and civil servants when asked about their dream. There is nothing wrong with that, however, their purpose of the study is becoming just to pursue their dream. Those who failed are often regarded as unsuccessful or failure.

Whilst the non-formal aspect is the youth that deviate from the education procedure and state's interest. In the nonformal context, they're not considered unlucky in their education, in fact, they're also educated to some extent. However, they chose another path or fail in competing for an opportunity. Though the youth compete for existing opportunity, they do not automatically construct value, norm, knowledge, status, and social role as their means for competing. Some chose the nonformal path since the beginning. Those who chose this path tend to create a shortcut and a leap of thought, making them tend to work in a non-formal sector such as creative entrepreneurship or involved in the development of civil society.

For the youth, both aspects emerge not separated, but intersecting each other creating an "arena". The youth as a competitor, at once, are faced with the risk of success and failure. Both risks are a part of the construction that the society built themselves. We can still remember back in the new order era there was a construction of success, the youth were pushed into the formal path, resulting doctor, engineer, soldier, and civil servant as their dream job. Right now, the construction of success is more supple and inclined to the non-formal path that is considered capable to create its own construction of success.

Furthermore, in the process both aspects are shadowed by failures, some of them are; First, the youth are trapped in a pragmatic assumption, meaning there are youth that solely follow the flow of change without critically thinking about the change taking place. Second, individualistic youth, those who only think for themselves and their group. The tend to behave in a way that avoid conflict and not willing to involve in solving a problem. Third, there are youth that think dichotomously, thinking that they are a victim of authority and therefore doing resistance (Robinson, 2016). Moreover doing anarchic activity and tend to be pathological. These three types of failure are also twisted in the same coil, enabling the youth to get out of the transition period by responding to one of the aspects. On the contrary, there are youth that fail to adapt to both aspects and got thrown into a more complex problem such as terrorism and drug dealing. 
This article explains such problematic by opposing the argument that Yogyakarta supposedly create a harmonisation of both aspects (formal and non-formal) simultaneously, which is not entirely true. The problem arises over the formal aspect. The large youth magnitude in Yogyakarta such as the large number of universities brings a new problem. The availability of job does not match the number of university graduate job seeker causes an income trap. It is showed by the difference between university graduate job seeker and the available job that is filled mostly with jobs for high school or vocational high school graduate. As a result, university graduate and high school or vocational high school graduate becoming more degraded in technical and manual labour. Contrarily, this nation only produces a more degraded labour/worker and lacks of critical thinker that can compete globally to develop this nation. Responding this problem creates two opinions, first, the government fails in responding youth's dynamic school to work transition. Second, these rapid changes in the youth is hard to be followed by the society and even by the government due to certain attributes such as bureaucracy.

From sociology side, the youth face social changes, both cultural and political, that can not be avoided in their lifetime. The risk of changes even has become the part of youth's life in their social transition phase (France, 2007; Furlong \& Cartmel, 2007, in Sutopo \& Meiji, 2014).

Special Region of Yogyakarta intentionally chosen as the location of study in this article because it's known as an education city, beside that Yogyakarta also developing into industrial that attracts youth job seekers just like Jakarta. As an educational city, it turns out that it still has a relatively high amount of youth open unemployment reaching $18,68 \%$ in 2010 . This condition changed at 2015 into $11,95 \%$ (Statistik Pemuda Indonesia 2010, Statistik Pemuda Indonesia 2015). The decline of open unemployment does not mean that workforce were absorbed into a productive sector corresponding to their education.

The perspective of the youth transition, explains two aspects which are that the transition as a space and time, and the youth as the agent of the transition (Parker \& Nilan 2013; Furlong \& Cartmel 2007) Certainly, there are differences in responding changes between the youth and other generations, this condition shows that the youth as the creator and at once the doer of the change itself.

This article's theoretical argument started with discussing the relation between the youth as an actor of transition with the embedded concept of value and norm. Despite sociologically the youth often positioned as an object rather than a subject. This matter then deceive us to discuss the pathological dimension instead of its productive dimension.

From economic side, education, skills, and experiences affect individual income level, especially if the individual categorised into several levels (Lemieux, 2006). This caused by education that gives skills towards the individual, enabling it to process output effectively and efficiently. Moreover, skill difference can happen among the group of educational level as well as inside an educational level group.

However, education is not the sole factor that affects individual income. Income can be affected by experiences or the work hour spent dealing with the job (Juhn, 1993). On the other side, income also affected by the quality of education received by the individual.

Past studies about income and productivity has been done such as by Effendi (2016). In the study, it is explained that productivity and income are not directly proportional. In the case of Indonesia, productivity encounter increase from year to year, whereas income experience stagnant increase. Indicating that workers don't get the benefit of increasing their productivity. 
Furthermore, the second study done by Wenth in Klinken \& Berenschot (2016:141167) about entity and work ambition of youth in Pontianak shows that there is work segregation based on entity, this caused by culture and work orientation of the youth referring to identity construction that affects income, and access to socio-economic resources of youth job seekers in Pontianak, East Borneo.

Third study done by Ananta \& Arifin in Darwin (2010:87-118), in their paper titled Migration, Ageing, and Economic Development in Indonesia shows the relation between the background of the paper that states demographic transition is happening in global, regional, and local level, that affects the means of migrating. Data gathered in Yogyakarta shows types of migrant between 1995-2000, which is Inter Province as much as 19.586 or $74,56 \%$ and Intra Province 67.019 or $25.42 \%$. It indicates that Yogyakarta is dominated by Inter Province migrant, and less than $30 \%$ migration happening between districts in the province. As for the means of migration most of the part are educational and job seekers in service and trade sector.

\section{Finding and Discussion}

Yogyakarta as a city of education has various potential and strength. Generally, Yogyakarta's economic potential lies on the youth and education. With such great potential, this province has a main force in moving the economy. As can be seen in graph 4.1, Yogyakarta's economic strength potential has gone through some change since 2008.

The change covers domestic income that came from the agriculture sector. Agriculture sector experienced a significant decline in the past 10 years. As a substitute, trading, financial, and services sectors have increased. Currently, the percentage has reached $60 \%$. The change has its explanations. Indonesia's economy has transformed structurally from manufacturing products into services. This transformation causes the field of work and type of work aspects to be becoming more diverse. This raises a question because the agriculture sector that has been giving jobs to many people facing a decline in its contribution towards the economy.

Diagram 4.1 Gross Regional Domestic

Product of Yogyakarta Province

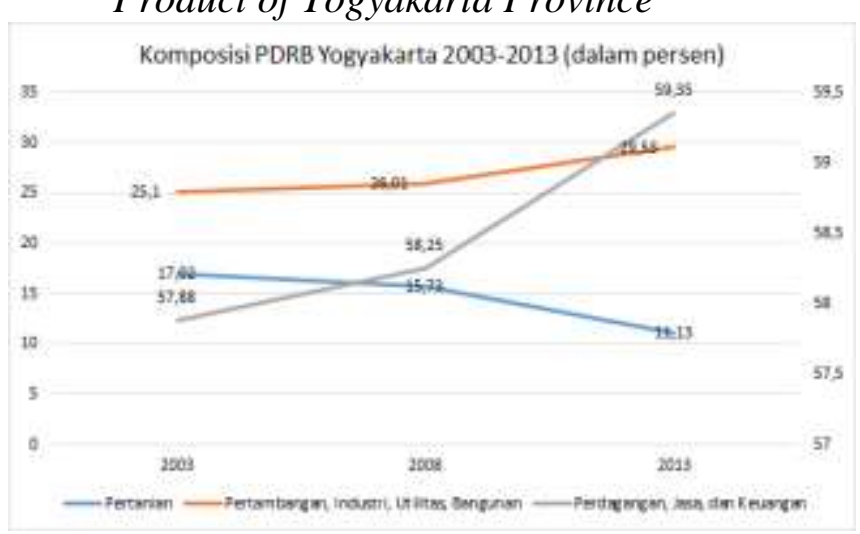

Source: Badan Pusat Statistik (2016), processed

From employment side, agriculture does not attract people as a field of work due to lack of strong national movement, organisation or political party representing their intersts (White, 2015). Transformation of agriculture into services can be seen in graph 4.2. Whereas manufacture faced an insignificant change. In 2003, 1 of 4 people worked in the agriculture sector. Yet, the situation changed in 2013 where only 1 of 10 people working in the agriculture sector. Agriculture sector are less attractive because it has a low productivity. Plus the fact that agricultural land can be owned by several individuals (agricultural involution).

In the period of 2003 until 2013, worker starts moving to the trading sector, communication, and financial. This phenomenon was caused by the fast growth of services sector giving direct benefits. In fact, in 2013, almost 7 of 10 people worked in such services sector. Even though, services require high capability in order to give a 
better quality. Such quality will encourage services product to have an excellence that can be developed. Moreover, services sector was chosen because it is related to youth education. When the youth thrive from majority middle school to majority high school educational level, the chance to work in diverse services sector is opened. This is what drive Yogyakarta's economy.

\section{Graph 4.2 Percentage of Youth Working by Field of Work}

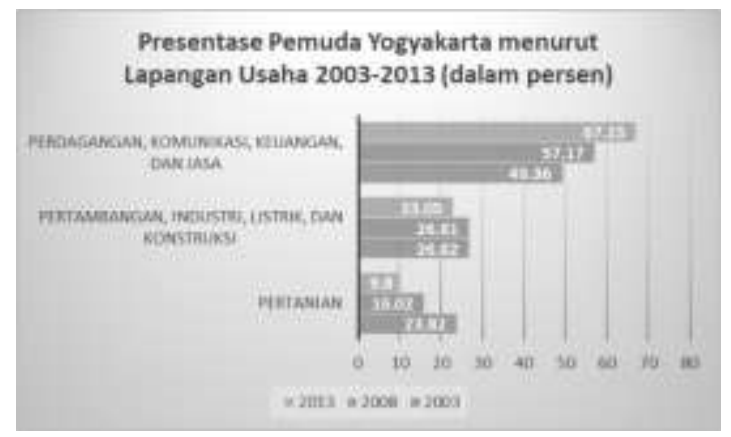

Source: Badan Pusat Statistik (2016), processed

The transition of employment sector in Yogyakarta must be connected into field of work or type of work that youth involved. We analysed that the changing of employment sector is from agriculture to service sector. Graph 4.3 shows that youth employment status in Yogyakarta has evolved from family-based worker into paid worker.

Looking at the field of work, it turns out that youth in Yogyakarta play a role in paid work. Either labour or employee depends on the wage or salary. Besides, this type of work susceptible to the risk of inflation perceived by workers. This is due to Yogyakarta's education system that is focused on making paid worker, so that the involvement of the worker is still minimal.

Even though the majority of work is at services sector, entrepreneurship sector that is being promoted by the government does not attract the youth in Yogyakarta. The youth are more attracted to be salarymen.
This raises a question whether or not the youth in Yogyakarta can undesrtand their province potential. Interestingly, family based worker are declining since 2003. The family-based workers made up $15,4 \%$ of the workforce, while in 2013, they only did $7,6 \%$. This shows that family does not become the basis of economic chosen by the youth of Yogyakarta.

\section{Graph 4.3 Yogyakarta's Youth Empolyment Status}

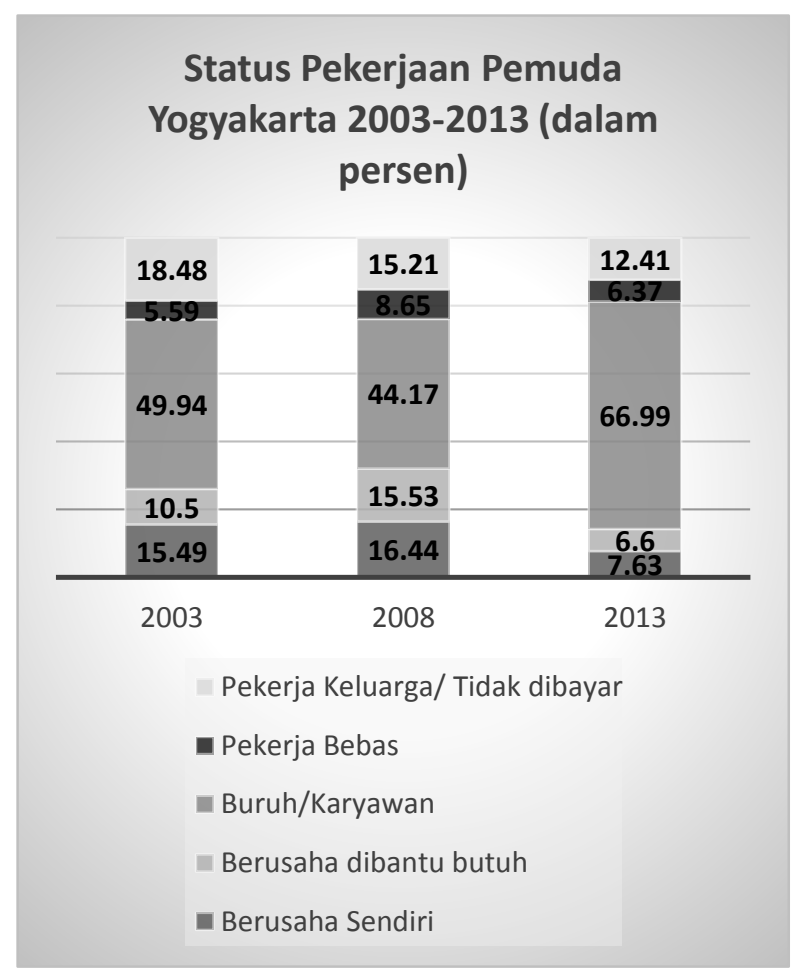

Source: Badan Pusat Statistik (2016), processed

From educational side, Yogyakarta's youth that works as an employee have high school degree or its equivalent. In 2008, most of the youth that works have only elementary school degree. The massive development of education during 2008-2013, enabling the worker to obtain middle and high school degree. But, the increase of middle school 
degree percentage is not significant in promoting worker skills.

From 2008 to 2013, the youth in Yogyakarta have succeeded to achieve higher education. Almost half of the youth working have high school degree. Yet, as seen on graph 4.4 the percentage of the worker with middle school degree does not decline significantly. It means that there is youth that trapped in middle education and have not been able to continue to a higher level of education. If they are trapped in lower education, they have lower potential to earn money.

\section{Graph 4.4 Yogyakarta's Youth Education Accomplishment}

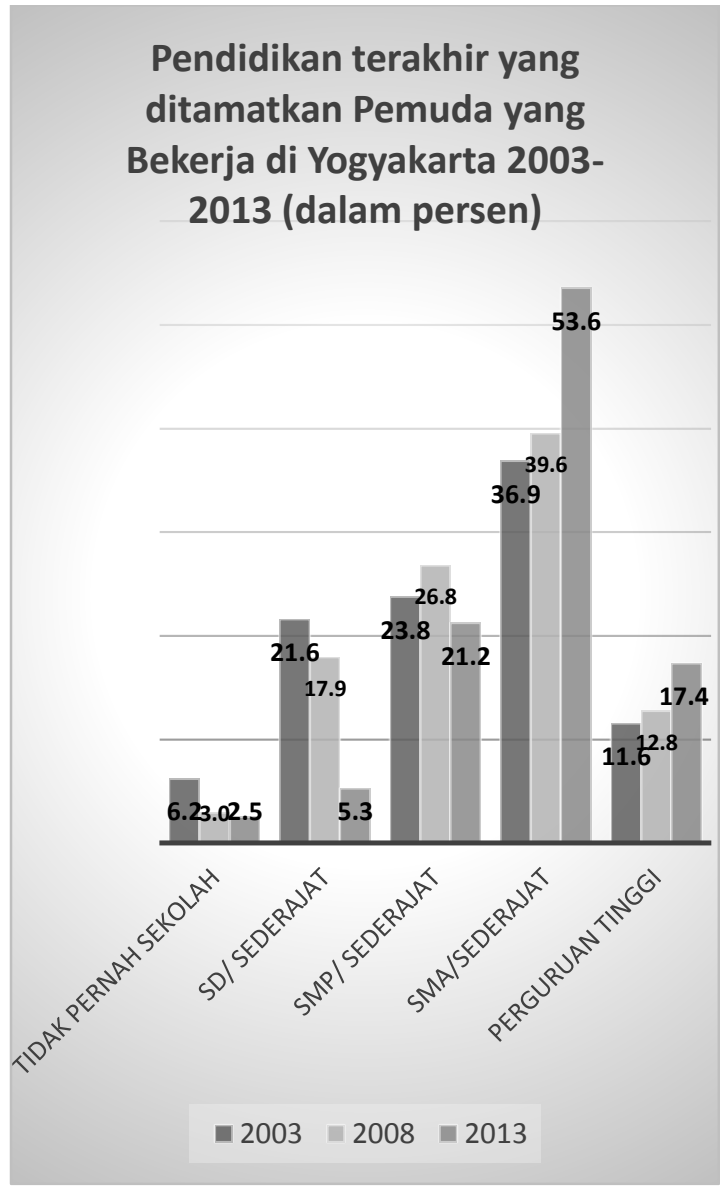

Source: Badan Pusat Statistik (2016), processed

When the youth failed to make a school to work transition, the education benefit, the percentage of earnings received due to accomplishing certain education can be lessened. Even though, with educational transformation, potentially, there are changes of income composition of the youth in Yogyakarta. With the gradual transition, the youth are able to have a higher level of income. Generally, nominal of income level has been increasing from year to year during 2008 until 2013. However, most of the income still ranging from 500 thousand until 1.5 million rupiahs.

Only in 5 years, nominal income has been increasing remarkably. In 2008, only $10 \%$ of the youth have higher income than 
1.5 million rupiahs, in 2013, almost $25 \%$ of the youth have higher income than 1.5 million rupiah. This may causes inequality between Yogyakarta citizens that are growing bigger each year.

Looking at income composition, there are less than $80 \%$ people whose income are lower than 1 million income in 2008. But, in 2013, that income reduced but bigger than $50 \%$. If people do not run into changes of income composition there will be a decrease in purchasing power.

\section{Graph 4.5 Income Composition}

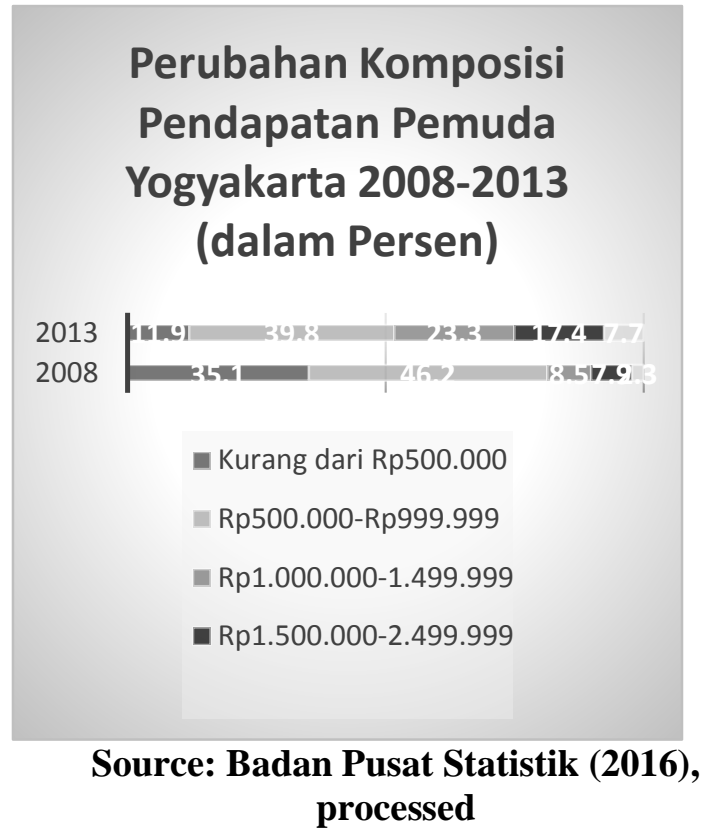

Further analysis using IFLS data, the salary that earned by the worker in Yogyakarta per month encounter an increases. Graph 4.5 shows the average income based on education accomplished. Based on cross tabulation, income received by elementary school graduates were only 160 thousand rupiahs in 2007. This condition changed into 518 thousand in 2014. The change in those two years is 2.2 times compared to base year.

Different with elementary graduates, middle school graduates have a higher average income, but not much different from elementary graduates, which was 234 thousand rupiahs in 2007. In 2014, their income rose to 670 thousand rupiahs. The change of income in those two years are 1.8 times compared to base year.

Besides, high school graduates receive an average of 333 thousand rupiahs in 2007. This condition changed at 2014, where the average income received became 936 thousand rupiahs. This shows a change of income as much as 2.5 times compared to base year.

From the graph, only those who have higher than undergraduate degree earn more than 5 million rupiahs per month. This condition is quite unique because the increase of nominal income does not slow down at a higher level of education, data shows that high school level has great increase of income.

Besides that, only those who have higher than undergraduate degree enjoy higher than 5 million rupiahs per month. This condition is happening and shows an increasing income inequality. But, the data from IFLS have not covered worker in the informal sector so it can be biased. On one side, the worker will be more interested in income changes in high school level. So that after high school, the worker doesn't feel a great increase of income. In the reality, income generated enlarge nominal differences among worker. 


\section{Graph 4.5 Cross Tabulation of Yogyakarta's Average Income}

\begin{tabular}{|l|c|c|c|}
\hline $\begin{array}{l}\text { Accomplis } \\
\text { hed } \\
\text { education }\end{array}$ & $\begin{array}{l}\text { Average } \\
\text { income } \\
\text { (thousand } \\
\text { rupiahs) }\end{array}$ & $\begin{array}{l}\text { Average } \\
\text { indome } \\
\text { (thousand } \\
\text { rupiahs) }\end{array}$ & $\begin{array}{l}\text { Change } \\
\text { of } \\
\text { income }\end{array}$ \\
\cline { 2 - 4 } & IFLS 2007 & IFLS 2014 & In ratio \\
\hline $\begin{array}{l}\text { Elementar } \\
\text { y }\end{array}$ & 160 & 518 & 2.23 \\
\hline Middle & 234 & 670 & 1.86 \\
\hline High & 333 & 936 & 2.57 \\
\hline $\begin{array}{l}\text { Undergrad } \\
\text { uate (S1) }\end{array}$ & 660 & 1.410 & 1.13 \\
\hline
\end{tabular}

Source: IFLS (2009); IFLS (2016), processed

Nominally, the reciprocity of education due to worker accomplishing higher education will be lower than before. However, this does not happen in Yogyakarta. The biggest change happened to high school degree, which is the precondition on many fields of work Yogyakarta is a mix of education and services economy city, with such great potential the youth should have opportunities for higher education, and opening up entrepreneurship. However, what is happening is the opposite. The youth are more interested with jobs with fixed salary. This group is vulnerable to the risk of inflation, or the up and down of economic cycle. Relying solely on salary, the youth employees do not have a share in the company and becoming only an object of services economy.

Furthermore, responding the data, the public policy orientation that should strive. The government should realise the importance of services economic structure in the youth of Yogyakarta. The youth should be invited to contribute in entrepreneurship, and becoming the subject or doer of regional development. The second thing is to facilitate the educational transition from middle to high school, certainly with necessary skills to contribute to the workforce market. Therefore, the composition of the worker in
Yogyakarta have to be changed so that the youth worker do not depend solely on salary. Failure of transition will make Yogyakarta trapped in low income.

\section{Conclusion}

The educational transition towards youth work is an important aspect to be noticed by the policy maker in the current competitive era. The effort to encourage the educated youth is not enough in preparing competitiveness of the productive human resources of demographic dividend. A transition roadmap is needed towards youth work that meets educational needs with available work on the regional and national level. On the contrary in 2035 this country will reap the ageing generation of current demographic dividend.

The educational sector holds a central role in giving employment opportunity especially the youth. The reciprocity of educational sector needs to be further reviewed because the youth in Yogyakarta still become an object, rather than a subject or the actor of regional human resource development. The failure of school to work transition of the youth in Yogyakarta shows that they are still trapped in nominal wage and vulnerable towards the financial risk.

On the other side, government policy in giving a steady transition towards the youth have to be done, so that the worker in Yogyakarta have a higher income level compared to unskilled worker. Therefore, this study takes a position as reflective study due to the use longer data interval. Although taking place in only three junctures, the changes can be spotted in the dynamic of education and income development.

****** 


\section{References}

Badan Pusat Statistik (2003), Statistik Pemuda Indonesia 2003

Badan Pusat Statistik (2008), Statistik Pemuda Indonesia 2008

Badan Pusat Statistik (2010), Statistik Pemuda Indonesia 2010

Badan Pusat Statistik (2013), Statistik Pemuda Indonesia 2013

Badan Pusat Statistik (2015), Statistik Pemuda Indonesia 2015

Chongvilaivan, Aekapol, dan Jungsuk Kim (2015), "Individual Income Inequality and Its Drivers in Indonesia: A Theil Decomposition Reassessment", Social Research, Vol.126 (1):79-98. DOI: 10.1007/S11205-015-0890-0

Darwin, Muhajir (ed) (2010), Dinamika Kependudukan dan Penguatan Governance, Yogyakarta, Media Wacana.

Furlong, Andy \& Cartmel, Fred. (2007).Young People and Social Change: New Perspectives. USA: Open University Press.a

Gerry van Klinken \& Ward Berenschot (ed) (2016), In Search of Middle Indonesia, Kelas Menengah di Kota-Kota Menengah, Jakarta, KITLV dan Yayasan Pustaka Obor Indonesia.

International Labour Office (ILO) (2004), Youth Employment Report in Indonesia: an update, Jakarta, (ILOLPEM-FEUI).

Juhn, Chinchui, et al. (1993), "Wage Inequality and the Rise in Returns to Skill”, The Journal of Political Economy, Vol. 101 (3): 410-442

Kuncoro, Mudrajad (2013), Metode Riset untuk Bisnis \& Ekonomi Edisi 4, Jakarta, Penerbit Erlangga

Lemieux, Thomas (2006), "Postsecondary Education and Increasing Wage
Inequality", American Economic Review, Vol. 96(2):196-199.

Parker, Lyn \& Nilan, Pam. (2013).Adolescents in Contemporary Indonesia. USA: Routledge.

Sutopo, Oki Rahadianto, \& Meiji N (2014), Transisi Pemuda dalam Masyarakat Resiko: Antara Aspirasi, Hambatan dan Ketidakpastian, Vol.11. No.3:1164-1186.

Sutopo, Oki Rahadianto. 2013, "Hidup adalah Perjuangan: Strategi Pemuda Yogyakarta dalam Transisi dari Dunia Pendidikan ke Dunia Kerja" Jurnal Sosiologi Masyarakat, Vol.18, No.2, Juli 2013: 161-179.

Robinson K, (ed), (2016) Youth Identities and Social Transformation in Contemporary Indonesia, Leiden, Brill

Strauss, J., F. Witoelar, B. Sikoki, dan A.M. Wattie, "The Fourth Wave of the Indonesia Family Life Survey (IFLS4): Overview and Field Report", April 2009, WR-675/1-NIA/NICHD.

Strauss, J., F. Witoelar, dan B. Sikoki, "The Fifth Wave of the Indonesia Family Life Survey (IFLS5): Overview and Field Report", March 2016, WR1143/1-NIA/NICHD.

Tadjoeddin, Mohammad Zulfan (2016), "Earnings, Productivity, and Inequality in Indonesia", The Economic and Labour Relations Review, Vol. 27 (2): 248-271

White, Ben (2015), "Remembering the Indonesian Peasants' Front and Plantation Workers' Union (19451966)", The Journal of Peasant Studies, Vol. 43 (1): 1-16

Woodman D, Bennet A, (ed), (2015) Youth Cultures, Transition, and Generations Bridging the Gap in Youth Research, New York, Palgrave Macmilla 